\title{
Spatial and temporal variability in marsh- water column interactions in a southeastern USA salt marsh estuary
}

\author{
Daniel L. Childers", Stephen Cofer-Shabica**, Lindsay Nakashima***
}

Baruch Marine Lab, University of South Carolina, PO Box 1630, Georgetown, South Carolina 29442, USA

\begin{abstract}
We measured the exchange of inorganic nutrients and particulate matter between the Spartina alterniflora marshes and the adjacent estuary of Cumberland Island, Georgia, USA, beginning in January 1991. Tidal fluxes were quantified using throughflow flumes at 3 sites within $10 \mathrm{~km}$ of one another. These sites represent a spatial gradient in geologic age, sediment characteristics, marsh topography and elevation, and exposure to open water that is often found in transgressive marshbarrier complexes. They exhibited large variability in frequency and duration of tidal inundation and in susceptibility of the marshes to wind and wave erosion. The flumes were sampled seasonally and on consecutive days, and we present flux data from 7 samplings. We also investigated short-term temporal variability in nutrient and particulate fluxes by sampling one flume 4 times in 6 days. Temporal variability in total and organic suspended sediment fluxes, which was largely related to quickly changing wind and wave conditions, was greater than spatial variability measured during the same time. Dissolved constituent fluxes were generally more variable across space, suggesting that day-to-day variability in dissolved nutrient exchanges was not a major contribution to spatial variability. Dissolved inorganic nutrient fluxes (as ammonium, nitrate+nitrite, and soluble reactive phosphorus) followed a spatial pattern of highest nutrient uptake at the geologically young marsh site. This marsh also consistently imported dissolved organic carbon. This site has the lowest absolute elevation of the 3 sites and a ramp-like topographic profile, and its young geologic age suggests that it is also ecologically immature. Fluxes of dissolved constituents at this site were negatively related to the area of marsh inundated, switching to export when large areas of the young marsh were inundated for long periods of time. This marsh also generally exported total and organic sediments; data from the other 2 sites were more variable. Sediment fluxes from the older marsh sites were positively related to slack high tide water level and area inundated, switching from particulates release to uptake only when the highest portions of these marshes were inundated. Most Cumberland Island marshes thus appear to take up sediments only when tidal heights exceed about $2.3 \mathrm{~m}$ above National Geodetic Vertical Datum, corresponding to tides where the moon is within $20 \%$ of new or full phase. Our data also suggest definite differences in the way the geologically young marshes interact with the inundating water column compared to geologically older marshes in the same estuarine system.
\end{abstract}

\section{INTRODUCTION}

Since 1980, a number of studies have quantified marsh-water column interactions directly by measuring nutrient fluxes through flumes built on the marsh

Present addresses:

- National Marine Fisheries Service, Southeast Fisheries Center-Galveston Lab, 4700 Avenue U, Galveston, Texas 77550, USA

- National Park Service, Cumberland Island National Seashore, PO Box 806 St. Marys, Georgia 31558, USA

-.Woodward-Clyde Consultants, PO Box 66317. Baton Rouge, Louisiana 70896, USA surface (Lee 1979, Wolaver et al. 1980, 1983, 1985 , Wolaver \& Zieman 1984, Chalmers et al. 1985, Bowden 1986, Childers \& Day 1988, Wolaver \& Spurrier, 1988a, b, Whiting et al. 1989, Childers \& Day, 1990a, b). Most marshes appear to import organic and inorganic suspended sediments, although a review by Stevenson et al. (1988) suggested that differences in tidal dynamics, seasonal changes in sea levels, and temperature may explain latitutidal variation in sediment trapping by marsh systems. A recent review of marsh-water column flux studies using the marsh flume technique suggested that (1) nutrient and organic matter fluxes were positively related to pre- 
dicted tidal range; (2) suspended sediment fluxes were negatively related to tidal range; (3) slopes of these relationships (flux rates) were greater in geologically younger marshes; and (4) the break between import and export consistently occurred at a range of about $1 \mathrm{~m}$ (Childers 1993). In this paper, we report results from an ongoing flume study conducted in mesotidal salt marshes on the Cumberland Island National Seashore, Georgia, USA.

Results from past flume studies highlight an interestuary variability in marsh-water column exchanges that is similar to the differences in estuary-coastal ocean fluxes summarized by Nixon (1980) and Dame (1993). This variability may be a result of differences in several physical factors, including geomorphology, tidal range, and freshwater influences (Odum et al. 1979). Within a given estuary, the locations chosen for flux studies may also be important, particularly in transgressive estuarine systems where differences in the geologic age of marshes (Gardner \& Bohn 1980) may affect ecological processes (Hayden et al. 1991, Dame et al. 1992, Dame \& Gardner 1993). In the past, flume studies have been carried out using 1 flume per estuary, or 1 flume per major marsh type (e.g. salt marsh, brackish marsh). This type of single-site research does not address the spatial differences in marsh morphology or geologic age within a single estuary or marsh type, or the effects those differences



Fig. 1 Conceptual diagram of the marsh morphodynamic model, relating environmental forcing functions (circles) to algorithms calculating a vectorized exposure index and a fractal-like measure of marsh physical characteristics. These parameters will be used to link the short-term flume flux data to longer-term sedimentation data in a site-specific manner at the ecosystem level, then in the more broad-scale context of barrier island-estuarine dynamics at the landscape level have on marsh-water column exchanges. As an example, the marsh flume used in an intensive study at North Inlet, South Carolina, USA (Wolaver et al. 1985, others) was located in a geologically young marsh and fluxes were probably not representative of older, more mature marshes elsewhere in that estuary (Dame et al. 1991). Notably, in a recent review of marsh flume studies, Childers (1993) reported that data from flumes in geologically younger marshes showed consistently greater flux rates at any given tidal range compared to data from geologically older marshes, suggesting a successional shift in flux dynamics along developmental (age) gradients, even within the same estuary.

Our primary objective in this study was to investigate spatial and temporal variation in marsh-water column interactions within a single estuary, and the effects that differences in (1) relative geologic age, (2) exposure to open water, and (3) marsh topographic profiles have on those variations. Dissolved and particulate nutrient exchanges were quantified seasonally at 3 Cumberland Island marsh sites using a hybrid throughflow marsh flume technique - this study presents data for the first 2 years. We also measured fluxes at 1 site on several consecutive days, and used those data to address the contribution of shortterm temporal variability to the observed spatial differences in marsh-water column interactions. We hypothesized that: (1) climatologic/hydrologic forcing would strongly affect the magnitude and direction of ticulate fluxes, with a tendency towards sediment exposed sites; (2) dissolved nutrient fluxes would be greater at sites where inundation rates her (a function of topographic variability), but flux rates would be largely independent of physical forcing; and (3) geologically younger marshes would take up nutrients and organic matter while releasing sediments at greater rates than older marshes.

This flume study is being coordinated with several other studies simultaneously quantifying short-term sediment deposition and seasonal and long-term changes in sediment elevation at the 3 sites (R. Boumans, D. Childers, L. Nakashima \& D. Reed unpubl.). An ultimate goal of our research effort is to develop a model based on this large data set relating marsh-water column exchanges and net sedimentation to marsh geomorphology (as a physical representation of marsh geo- 
logic age) and climatological forcing in the context of the marsh ecosystem and the coastal landscape. This model is conceptualized in Fig. 1. Forcing functions and response factors in this model will include (1) vectorized wind direction and speed data; (2) sedimentological and botanical marsh characteristics; (3) inundation data from water level records; (4) a fractal-type representation of marsh topography and marsh edge orientation; and (5) from that fractal model, a measure of the degree of exposure. The model will first mechanistically simulate, at the ecosystem level, both short-term flux patterns and longer term net accretionary trends at our 3 specific sites. As our fractal representation of (2-dimensional planar) marsh edge and (1-dimensional vertical) topography becomes more complete, the model will simulate these relationships over longer time periods and in the spatial domain of the entire barrier island-estuarine system (Fig. 1). This landscape-level simulation will intrinsically incorporate the feedbacks between exposure and fluxes, sedimentation and topography, and geologic age and geomorphology, effectively integrating spatial measurements made in several time frames into a spatially articulate predictor of salt marsh morphodynamics. The marsh-water column exchange data we present here is critical to the linkage of short-and long-term dynamics in this model.

\section{MATERIALS AND METHODS}

Study area. Cumberland Island $\left(31^{\circ} \mathrm{N}, 82^{\circ} \mathrm{W}\right)$ is the southernmost and largest of Georgia's barrier island system. Part of the Cumberland Island National Seashore (established in 1972), the 13300 ha island is $26 \mathrm{~km}$ long and includes 6800 ha of marshes, mudflats, and tidal creeks. The island is characterized by extensive dune fields to the east, along the Atlantic Ocean shore, an old-growth maritime forest interior, and extensive Spartina alterniflora salt marshes along the western margin bordering Cumberland Sound (Fig. 2). Pleistocene and Holocene sediments compose the surficial sediments of Cumberland Island. The adjacent St. Marys and Satilla Rivers carry little sediment to the mesotidal barrier system. Semidiurnal tides generate a mean tidal range of $1.9 \mathrm{~m}$ and spring range of $2.9 \mathrm{~m}$. Salt marshes at the southern end of the island are sandy and exposed to the lengthy fetch of Cumberland Sound, while marshes to the north are silty and protected by the more expansive intertidal system. Three sites were established: Site 1, at the southern tip of Cumberland Island, with sandy sediments, low macrophyte biomass [short Spartina alterniflora (primarily) and some Salicornia sp.], and very exposed; Site 2, further north, also exposed, but with silty sediments and intermediate macrophyte biomass (dominated by

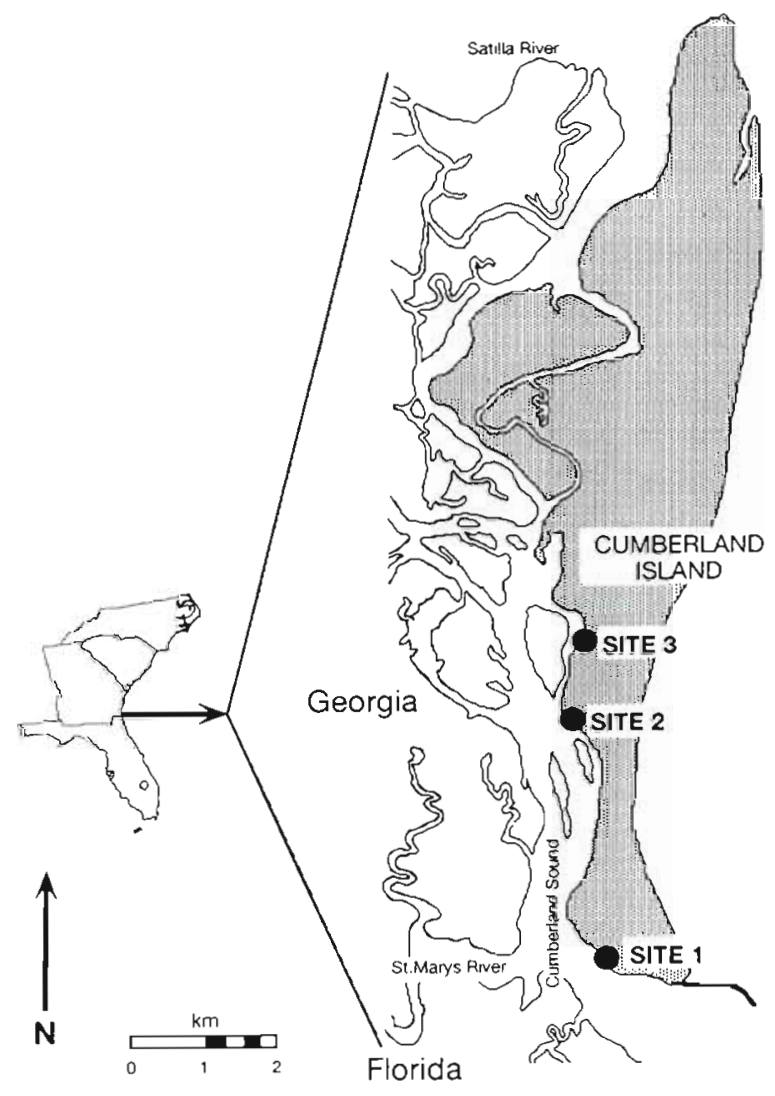

Fig. 2. The Cumberland Island estuary with the locations of the study sites. Note the variable degrees of exposure of each to open water and extensive fetch

Spartina alterniflora); and Site 3, the northernmost site, also with silty sediments but protected, and the highest macrophyte biomass (also dominated by Spartina alterniflora; Fig. 2). There is also a north-to-south topographic and elevational gradient in which Site 3 has a higher elevation than Site 1 and has a classic bermtype marsh profile as compared to a ramp-like profile at Site 1. Again, Site 2 has intermediate characteristics (Fig. 3).

Marsh flume technique. A $2 \times 30 \mathrm{~m}$ throughflow flume was built from the creekbank normal to the marsh edge at each marsh site shown in Fig. 2. We used a hybridization of the techniques of Wolaver et al. (1985), Childers \& Day (1988), and Spurrier \& Kjerfve (1988) to calculate fluxes through the flumes. Flumes used by Wolaver et al. (1980, 1983, 1985) in Virginia and South Carolina (USA) were built from the creekbank through the high marsh to uplands. As a result, they were sampled only at the creek end and it was assumed that the water leaving the flume on the ebbing tide was the same water that entered on the flooding tide. In the flat, microtidal marshes of Louisiana (USA), shorter throughflow flumes were built, and were sampled at both ends simultaneously (Childers \& 


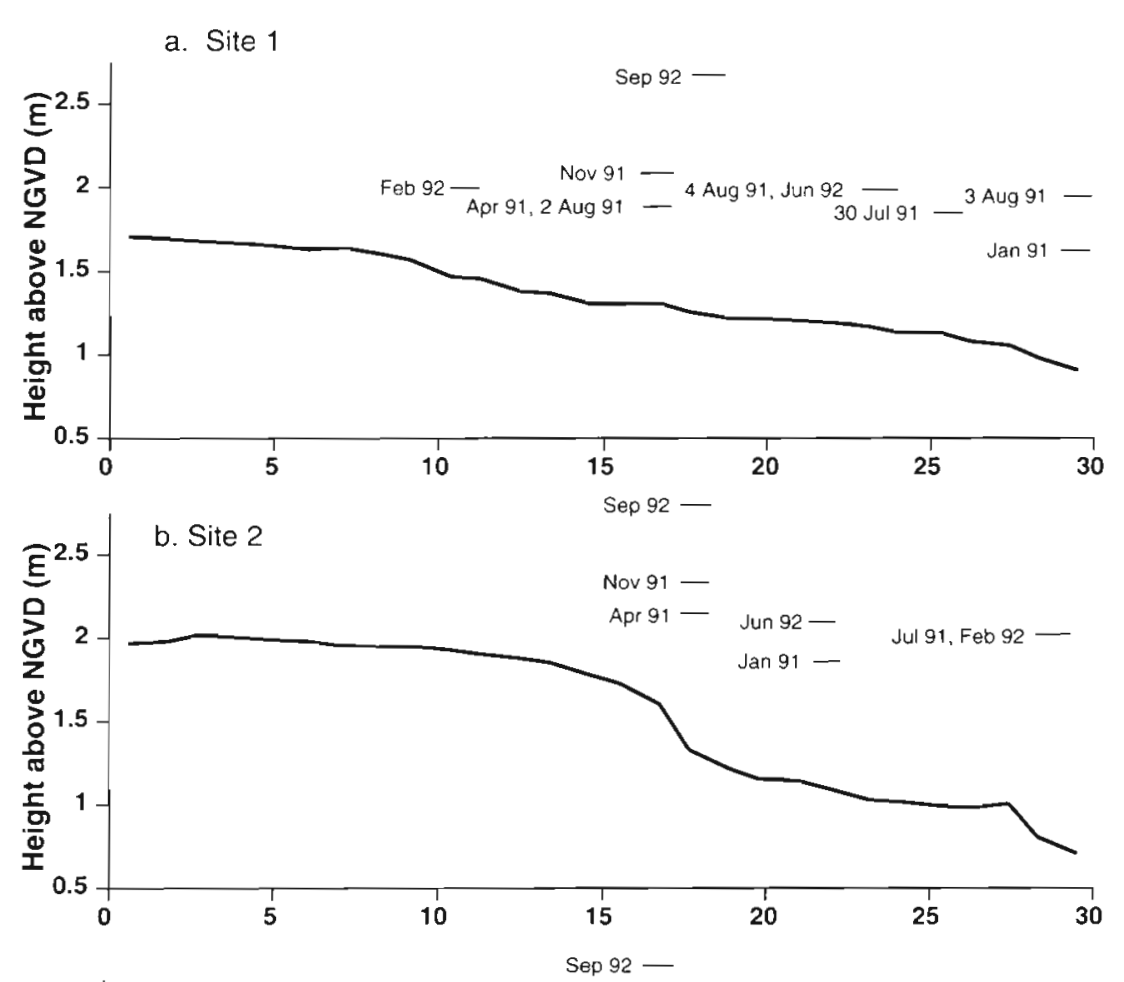

fluxes were exports from the marsh and positive fluxes were imports to the marsh. Fluxes (calculated as mg constituent $\mathrm{m}^{-2}$ marsh inundated $\mathrm{h}^{-1}$ of inundation) were based on concentrations, as means of replicate samples, multiplied by the volumetrically-determined water flux. At any given time, the volume of water contained within each flume was a function of water level, water velocity, and the microtopography of the marsh (Fig. 3). The data from the 2 August 1991 sampling at Site 1 demonstrate how fluxes were calculated (Fig. 4). Water volume was calculated each time a sample was drawn by combining marsh topography (Fig. 3) with water level (Fig 4a). Horizontal advection through our flumes was generally not measurable, but this advective component is critical to water flux calculations in flumes where flow is detectable (generally above 1 to $2 \mathrm{~cm} \mathrm{~s}^{-1}$ ). We determined instantaneous water flux $\left(\mathrm{m}^{3} \mathrm{~s}^{-1}\right)$ at the time each concentration sample was drawn by calculating the derivative of the water volume curve at that time. Instantaneous water flux multiplied by constituent concentrations from the water samples (in this example, TSS; Fig. 4b) was thus instantaneous flux (Fig. 4c, bottom panel), calculated for both ends of the flume (note that water flowed through the entire flume for only $\sim 2 \mathrm{~h}$ of the $>5 \mathrm{~h}$ tide). These curves were integrated, added together (retaining the

Fig. 3. Marsh flume topographic profiles with elevations (m above NGVD, National Geodetic Vertical Datum), showing (a) the ramp-like profile at Site 1, (b) the steplike profile at Site 2, and (c) the classic creekside levee profile at Site 3. Maximum water levels (at slack high tide) are shown for each sampling event at each site, by date. These elevations correspond to the HTWL data in Table 1

Day 1988). In those, fluxes were based on concentration differences before and after 'treatment' by the marsh within the flume. Cumberland Island marshes are topographically similar to the South Carolina marsh of Wolaver et al. (1985), but because the uplands were prohibitively distant we based our flumes on the open-ended throughflow design of Childers \& Day (1988).

In our hybrid method, we calculated flood tide fluxes as the total mass of a constituent entering the creek end of the flume minus total mass leaving the inland end, and vice versa for ebbing tides. We determined whole tide exchanges as a simple mass balance of these fluxes, following the convention that negative sign, or direction, of flux), and the resultant mass balance represented total flux of that constituent per hour of inundation. In samplings where the tide did not flood the entire flume - typical of neap tidal conditions at Sites 2 and 3 - the flux models were conceptually similar to the 'water in = water out' technique of Wolaver et al. $(1980,1983,1985)$ and Spurrier \& Kjerfve (1988).

Integrated areas of marsh inundated were determined similarly, generating constituent flux in $\mathrm{mg} \mathrm{m}^{-2}$ $\mathrm{h}^{-1}$ (for the Fig. 4 example, the net flux was $-27.3 \mathrm{~g} \mathrm{~m}^{-2}$ $\mathrm{h}^{-1}$ ). To determine $95 \%$ confidence intervals for fluxes, we used sample concentration means \pm sample standard deviations in the flux models (shown as fine 
a.
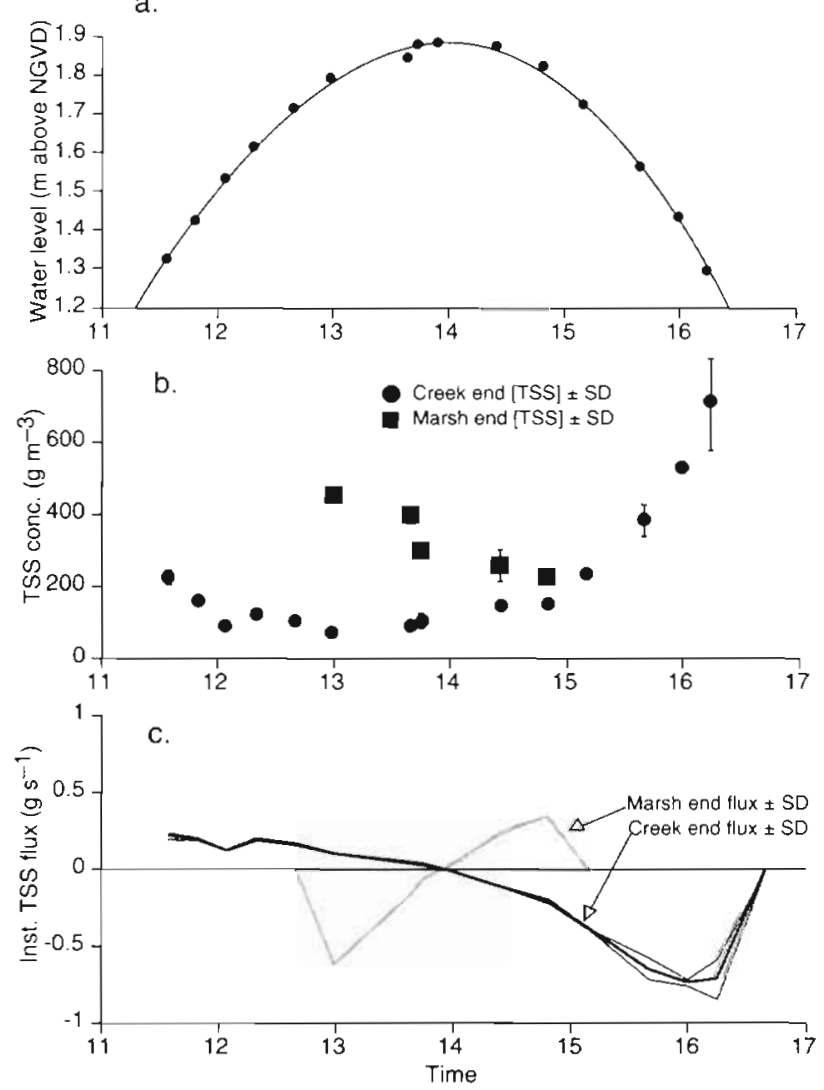

Fig. 4. Example of flux calculations using 2 August Site 1 data including (a) water level within the flume, (b) total suspended sediment (TSS) concentration sample means and standard deviations ( \pm SD) measured at the creek and marsh ends of the flume, and (c) instantaneous TSS flux calculated from water flux and TSS concentration means (bold line) and instantaneous TSS flux calculated using TSS concentration means \pm SD ('flux error term' from text; fine lines)

lines in Fig. 4c), acknowledging that most variability in these flux measurements was associated with sampling and analytical error. The $95 \%$ confidence interval was thus total flux \pm twice this flux error term (Sokal \& Rolff 1981), and where total flux \pm the confidence interval did not change sign (exports remained $<0$, imports remained $>0$ ), the flux was considered significantly different from 0 . The total flux calculated in the Fig. 4 example was significant because the confidence interval was $\pm 2.2 \mathrm{~g} \mathrm{~m}^{-2} \mathrm{~h}^{-1}$ (the flux error term was $1.1 \mathrm{~g} \mathrm{~m}^{-2} \mathrm{~h}^{-1}$ ).

The 3 flumes were sampled on consecutive days in January, April, July-August, and November 1991, and February, June, and September 1992. To assess the short-term temporal variability in fluxes, we also sampled the Site 1 flume on 4 of 6 days during July-August 1991. Replicate nutrient samples were immediately filtered through pre-ashed, pre-weighed glass fiber filters (Whatman GF-F) and frozen in the field. Technicon Autoanalyzer techniques were used to determine concentrations of ammonium $\left(\mathrm{NH}_{4}{ }^{+}\right.$; Method 154-71W/B), nitrate+nitrite $\left(\mathrm{NO}_{3}^{-}+\mathrm{NO}_{2}^{-}=\right.$ $N N_{;}$Method 158-71W), and soluble reactive phosphorus (SRP; Method 155-71W) concentrations (U.S. E.P.A. 1979). Total suspended sediment (TSS) and organic suspended sediment (OSS) concentrations were based on the dry weight and ashed weight of each filter respectively. Dissolved organic carbon (DOC) concentrations were determined using a Shimadzu Model 500 TOC analyzer. During all samplings, important physical variables, including wind speed and direction, wave action within the flume, and weather, were also monitored. When a rainstorm occurred during a sampling, we measured the amount and intensity of rainfall volumetrically and collected rainwater in an acid-washed container for nutrient analysis. Precipitation inputs were included in flux calculations.

\section{RESULTS}

The flux data were divided into analyses of spatial variability, using the seasonal samplings, and shortterm temporal variability, based on the intensive summer samplings at Site 1 . The importance of climatologic and hydrologic forcing as potential controls on the magnitude and direction of particulate fluxes was discussed above. The exposure of each site was thus a critical parameter, and varied greatly at the 3 sites. Site 1 was exposed to nearly $180^{\circ}$ of open water and to (westerly) winds from the southeast to the northwest, while Site 2 was affected by southwesterly to northwesterly winds $\left(90^{\circ}\right)$ and Site 3 was relatively protected (Fig. 2). Wind speed and direction relative to the marsh edge (and thus the flumes themselves) interact with the degree of exposure to open water to determine wave action, sediment transport, and potential marsh erosion or deposition. In Table 1, we detail the weather, wind speed and direction, and wave climate within the flumes during each sampling. Site 1 experienced the greatest frequency of wind-driven wave energy, with onshore winds exceeding 10 knots $\left(18.3 \mathrm{~km} \mathrm{~h}^{-1}\right)$ and wave heights within the flume exceeding $20 \mathrm{~cm}$ in 6 of 10 samplings. This compares to similar conditions in 2 of 7 samplings at Site 2 and no such wave conditions in the samplings at Site 3 (Table 1). Notably, the weather was considerably calmer during the November 1991 and all 1992 samplings.

Wind-driven waves cannot affect marsh-water column fluxes if the marsh is not flooded, and tidal range and different topographic profiles (Fig. 2) interact to determine the time and area of marsh inundation at 
Table 1. Hydrologic and climatologic conditions during each sampling in 1991 and 1992. Tide: percentage of full moon on each day, where $0 \%$ = new moon (spring set; maximum tidal range), $50 \%=$ half moon (neap set; minimum tidal range) and $100 \%=$ full moon (spring set; near maximum tidal range). HTWL: high tide water level (m), maximum tidal height above NGVD at slack high tide (also shown in Fig. 3). Area: integrated area of marsh within the flume inundated $\left(\mathrm{m}^{2}\right\}$. Weather: sky conditions, relative temperature, and events (ts: thunderstorms in the vicinity; rain: measurable rain at the site; p.c.: partly cloudy). Waves: wave heights through the flume, closely related to wind speed and direction relative to flume orientation. Wind direction is shown as true (compass orientations) as well as relative to the creek end of each flume. Note that flumes at Sites 2 and 3 are oriented $\sim E-W$, with the west ends opening to the tidal creek, while the flume at Site 1 is oriented $\sim$ SW-NE, opening to the tidal creek at the southwest end

\begin{tabular}{|c|c|c|c|c|c|c|c|c|c|}
\hline Date & Site & Tide & HTWL & Area & Weather & Waves $(\mathrm{cm})$ & Wind (knots) & \multicolumn{2}{|c|}{ Wind direction } \\
\hline 19 Jan & 3 & 26 & 2.09 & 44.6 & Overcast, drizzly, cool & Little/none & $\sim$ Calm & & \\
\hline $20 \mathrm{Jan}$ & 2 & 33 & 1.87 & 35.2 & P.c., cool & $\sim 20$ & $15-20$ & NNW & $\searrow=$ \\
\hline $21 \mathrm{Jan}$ & 1 & 40 & 1.62 & 27.4 & Clear, cool & $<10->20$ & $10-15$ & WNW & $y=$ \\
\hline $19 \mathrm{Apr}$ & 3 & 35 & 2.03 & 27.8 & Overcast AM, clear PM & Little/none & $\sim \mathrm{Calm}$ & & \\
\hline $20 \mathrm{Apr}$ & 2 & 42 & 2.14 & 42.0 & Overcast AM, p.c. PM & $<10$ & $5-10$ & WNW & $\rightarrow=$ \\
\hline $21 \mathrm{Apr}$ & 1 & 49 & 1.88 & 43.4 & Clear, cool & $20-30$ & $20-25$ & NW & $y=$ \\
\hline $30 \mathrm{Jul}$ & 1 & 73 & 1.86 & 44.0 & Clear AM, p.c. PM, ts & $<10$ & $10-15$ & $\mathrm{SE}$ & $\pi=$ \\
\hline $31 \mathrm{Jul}$ & 2 & 66 & 2.03 & 33.2 & Overcast, ts, $2.4 \mathrm{~cm}$ rain & $<10($ rain $>20)$ & $0-5$ & \multicolumn{2}{|c|}{ Gusty in ts } \\
\hline 1. Aug & 3 & 59 & 1.95 & 8.6 & Overcast AM, p.c. PM & $<10$ & $10-15$ & SW & $\lambda=$ \\
\hline 2 Aug & 1 & 52 & 1.88 & 42.6 & P.c., ts & $>30-<10$ & $20-25$ & SW & $\rightarrow=$ \\
\hline 3 Aug & $i$ & 45 & 1.93 & 45.2 & Mostly clear, some ts & Little/none & $0-10$ & WSW & $\rightarrow=$ \\
\hline 4 Aug & 1 & 38 & 1.99 & 46.0 & Clear and hazy, some ts & $20-30$ & $5-10$ & $\mathrm{~W}$ & $\searrow=$ \\
\hline $24 \mathrm{Nov}$ & 1 & 81 & 2.10 & 47.8 & Clear, cold & $10-20$ & $10-15$ & NW & $\searrow=$ \\
\hline 25 Nov & 3 & 74 & 2.17 & 33.4 & Clear, cold & Little/none & $5-10$ & $\mathrm{~N}$ & $\downarrow=$ \\
\hline $26 \mathrm{Nov}$ & 2 & 66 & 2.34 & 48.6 & Clear, cold & Little/none & $0-5$ & $\mathrm{~N}$ & $\downarrow=$ \\
\hline $21 \mathrm{Feb}$ & 1 & 78 & 2.02 & 52.8 & Cloudy, cool & Little/none & $5-10$ & $N E$ & $\leftarrow=$ \\
\hline $22 \mathrm{Feb}$ & 2 & 71 & 2.03 & 35.6 & Cloudy, warm & Little/none & 5 & E & $\leftarrow=$ \\
\hline $23 \mathrm{Feb}$ & 3 & 64 & 1.85 & 7.8 & Cloudy, warm & Little/none & 5 & $\overline{\mathrm{S}}$ & $\uparrow=$ \\
\hline $17 \mathrm{Jun}$ & 1 & 83 & 1.99 & 47.6 & Clear, warm & Little/none & $10-15$ & SE & $\uparrow=$ \\
\hline $18 \mathrm{Jun}$ & 2 & 77 & 2.10 & 42.8 & Clear, warm & Little/none & $5-10$ & $N E$ & $k=$ \\
\hline 19 Jun & 3 & 70 & 1.92 & 8.2 & Clear, hot & Little/none & Calm & & \\
\hline $26 \mathrm{Sept}$ & 3 & 2 & 2.86 & 50.0 & Overcast, cool & Little/none & $0-5$ & $\mathrm{NE}$ & $\kappa=$ \\
\hline 27 Sep & 2 & 9 & 2.82 & 58.0 & Clear, cool & Little/none & $5-10$ & ESE & $\kappa=$ \\
\hline $28 \mathrm{Sep}$ & 1 & 15 & 2.67 & 58.8 & P.c. to cloudy, drizzle & $10-20$ & $10-15$ & $\mathrm{NE}$ & $\leftarrow=$ \\
\hline
\end{tabular}

each site. Dissolved nutrient fluxes may be largely controlled by inundation rates (thus topographic variability) and seasonality but they may be largely independent of physical forcing. Table 1 also shows the tidal range relative to the spring-neap cycle (as \% of full moon during each sampling), maximum tidal height at slack high tide, and the integrated area of marsh in undated during each sampling. Because of the lower elevation and ramp-like profile of Site 1 , the marsh within this flume was flooded to a greater extent than the other sites - in fact, the tide was not high enough to inundate the marsh beyond the 'step' feature at Site 2 or the 'berm' at Site 3 on 4 of 7 samplings (January and July 1991, February and June 1992) and 3 of 7 samplings (August 1991, February and June 1992) respectively (also see Fig. 3). The only measurable rainfall occurred at Site 2 during an intense squall on 31 July 1991. In $15 \mathrm{~min}, 2.4 \mathrm{~cm}$ rain fell on the partly exposed marsh. This rainwater contained $7.8 \mu \mathrm{M} \mathrm{NH}_{4}{ }^{+}-\mathrm{N}( \pm 2.3$ $\mu \mathrm{M}), 14.6 \mu \mathrm{M} N \mathrm{~N}-\mathrm{N}( \pm 0.06 \mu \mathrm{M})$, and $0.09 \mu \mathrm{M}$ SRP-P $( \pm 0.06 \mu \mathrm{M})$, and using these concentrations we calculated inputs of $38.4 \mathrm{mg} \mathrm{NH}{ }_{4}{ }^{+}-\mathrm{N}, 71.9 \mathrm{mg} \mathrm{NN}-\mathrm{N}$ and $1.0 \mathrm{mg}$ SRP-P to the flume.

\section{Spatial variability in marsh-water column exchanges}

Significant fluxes of dissolved inorganic nutrients generally showed a seasonal trend of uptake in the spring and summer, and no exchange or release in the fall and winter (Fig. 5a to c). Site 1 imported ammonium year-round, though, with $\mathrm{NH}_{4}{ }^{+}$uptake in all 7 samplings and with uptake rates greater than those measured at Sites 2 and 3 in 6 of 7 samplings (Fig. 5a). The magnitudes of nitrate-nitrite fluxes were also generally lower at Sites 2 and 3 compared to Site 1, and in 4 of 7 samplings Site 1 flux was in the opposite direction from flux at Sites 2 or 3 (Fig. 5b). In 3 samplings, $\mathrm{NN}$ flux was high relative to $\mathrm{NH}_{4}{ }^{+}$flux. The large NN import in July 1991 at Site 2 occurred during the only rain event sampled to date (Table 1) and the flux calculated without this nitrate-enriched rain input was $1.04 \pm 0.23 \mathrm{mg} \mathrm{m}^{-2} \mathrm{~h}^{-1}$, a $41 \%$ reduction. In September 1992, NN imports at Sites 2 and 3 were considerably greater (by 3 to 4 times) than $\mathrm{NH}_{4}{ }^{+}$uptake measured at the same time (Fig. 5b), but rain during sampling was not the reason. Soluble reactive 

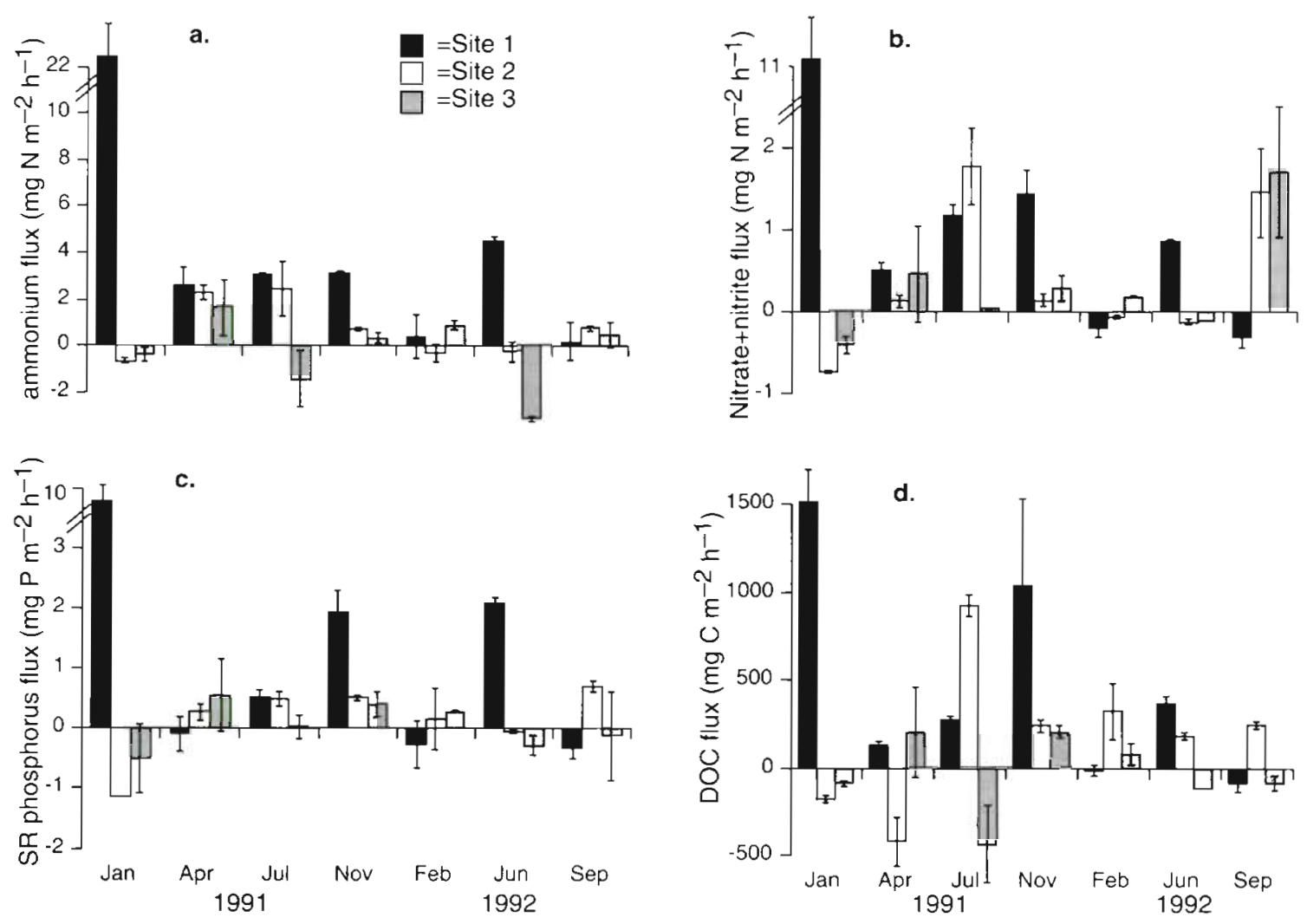

Fig. 5. Dissolved constituent fluxes $( \pm 95 \% \mathrm{Cl}$ ) across space (Sites 1, 2, and 3) for 1991-92: (a) ammonium flux, (b) nitrate+nitrite flux, (c) soluble reactive phosphorus flux, and (d) dissolved organic carbon flux. The following fluxes were not significant (95\% confidence level): (a) $\mathrm{NH}_{4}{ }^{+}$: Feb and Sep 1992 at Site 1, Feb and Jun 1992 at Site 2, Sep 1992 at Site 3; (b) NN: Apr 1991 at Site 3; (c) SRP: Apr 1991 and Feb 1992 at Site 1, Feb and Jun 1992 at Site 2, Jan, Apr and Jul 1991, Sep 1992 at Site 3; (d) DOC: Feb 1992 at Site 1; Apr 1991 at Site 3

P fluxes were low at Sites 2 and 3 - lower than SRP uptake at Site 1 in 4 of 7 samplings. As with the intersite NN flux pattern, SRP flux measured at Site 1 was in the opposite direction from Sites 2 or 3 in 5 of 7 samplings (Fig. 5c).

Dissolved organic carbon (DOC) fluxes were spatially variable in all seasons, with a different spatial combination of magnitude and direction of DOC exchange observed on all 7 samplings (Fig. 5d). Site 1 was generally characterized by DOC uptake, while DOC fluxes at Sites 2 and 3 were more variable. Whereas the dissolved inorganic nutrient flux data tended to implicate different exchange patterns at Site 1 compared to Sites 2 and 3, the DOC flux data showed no such spatial pattern. In fact, while Sites 2 and 3 had DOC fluxes of similar magnitude and direction in 4 of 7 samplings, the same similarities may be noted for Sites 1 and 2 and Sites 1 and 3 in 3 of 7 samplings each (Fig. 5d).

Marsh-water column exchanges of particulates showed a clearer spatial pattern. Site 1 exported TSS and OSS in all but 1 sampling, and the magnitude of these exchanges was consistently greater than at Sites
2 or 3 (Fig. 6). Also, the magnitudes and directions of particulates fluxes at Sites 2 and 3 were similar in all but one sampling, generally showing TSS and OSS uptake (Fig. 6). This pattern of particulates export from Site 1 and uptake at Sites 2 and 3 coincided with a markedly higher frequency of onshore winds exceeding 10 knots $\left(18.3 \mathrm{~km} \mathrm{~h}^{-1}\right)$ and wave heights within the flume exceeding $20 \mathrm{~cm}$ at Site 1 (Table 1). A lack of wave energy at Site 1, however, did not lead to spatially consistent particulates fluxes. Negligible wave energy was observed at all 3 sites in both February and June 1992 (Table 1), and in both cases Site 1 still exported TSS and OSS while Sites 2 and 3 imported particulates (Fig. 6). As noted above, an intense thunderstorm occurred while sampling Site 2 in July 1991, and the rainstorm $(2.4 \mathrm{~cm}$ in $-15 \mathrm{~min})$ occurred nearly $2 \mathrm{~h}$ into the ebbing tide. Over one-half of the marsh within the flume was exposed and, while we did measure a significant release of particulates on this tide (Fig. 6), the flux was not large. In September 1992, we sampled the flumes during a high (new moon) spring tide (Table 1). During this extreme flooding event, we measured TSS and OSS imports at Sites 2 and 3 that 

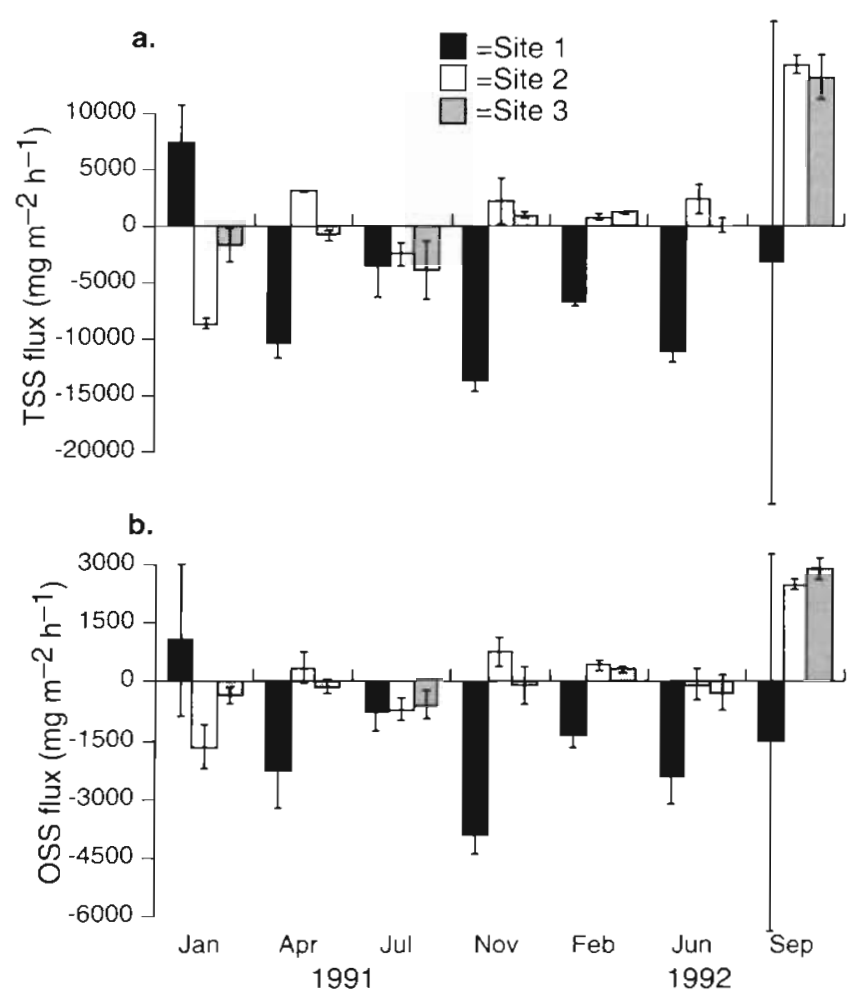

Fig. 6. Particulate constituent fluxes ( $\pm 95 \% \mathrm{Cl}$ ) across space (Sites 1, 2, \& 3) for 1991-1992: (a) total suspended sediment flux and (b) organic suspended sediment flux. The following fluxes were not significant (95\% confidence level): (a) TSS: Sep 1992 at Site 1, Jun 1992 at Site 3 (b) OSS: Jan 1991 and Sep 1992 at Site 1, Apr 1991 and Jun 1992 at Site 2, Apr and Nov 1991, Jun 1992 at Site 3

exceeded any other fluxes at these sites by (at least) 5 -fold while Site 1 again exported particulates, though variability about this flux was extreme (Fig. 6).

\section{Temporal variability in marsh-water column exchanges}

We investigated short-term temporal variability in marsh-water column exchanges at Site 1 in July-August 1991. We sampled the flume at this southern, exposed location 4 times in 6 days (30 July, 2, 3, and 4 August). Winds veered from SE (normal to the flume) on 30 July to SW (with SW directly into the flume), then to $W$, generally at 0 to 15 knots (Table 1 ). On August 2, intense nearby thunderstorm activity was accompanied by southwesterly gusts of 20 to $25 \mathrm{kn}$ that generated $30 \mathrm{~cm}$ waves into the flume for a short time. The Site 1 marsh exported particulates, both total and organic, throughout this period of time but showed only moderate temporal variation in fluxes except for the 2 August data (Fig. 7a). We used these Site 1 flux data and July 1991 data from all 3 sites to compare
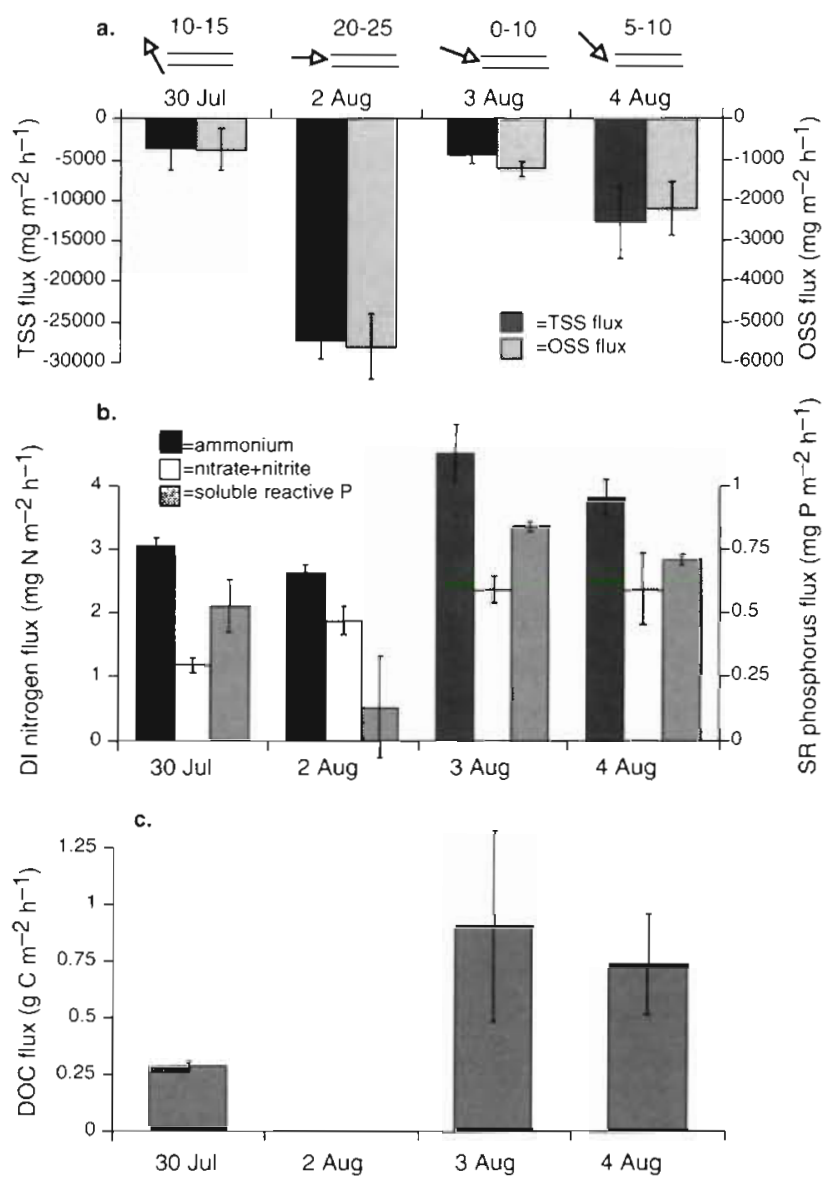

Fig. 7. Fluxes ( $\pm 95 \% \mathrm{Cl}$ ) over time (30 July to 4 August 1991) at Site 1: (a) particulates fluxes, (b) dissolved inorganic nutrient fluxes and (c) dissolved organic carbon flux. The wind vane diagrams indicate the average wind speeds (knots) and direction relative to the flume (the creek end of the flume is represented on the left). The following flux was not significant

(95\% confidence level): (b) Site 3: SRP flux on 2 Aug

temporal and spatial variability measured over the same 6 d time interval (compare Figs. 5, 6\& 7).

The temporal variability in observed TSS and OSS fluxes $\left(-3.6 \pm 2.7\right.$ to $-27 \pm 3.4 \mathrm{~g}$ TSS $\mathrm{m}^{-2} \mathrm{~h}^{-1}$ and -0.76 \pm 0.52 to $-5.6 \pm 0.8 \mathrm{~g}$ OSS $\mathrm{m}^{-2} \mathrm{~h}^{-1}$ ) was markedly greater than spatial variability $(-2.5 \pm 1.0$ to $-3.6 \pm$ $2.7 \mathrm{~g} \mathrm{TSS} \mathrm{m}^{-2} \mathrm{~h}^{-1}$ and $-0.76 \pm 0.52$ to $-0.61 \pm 0.34 \mathrm{~g}$ OSS $\mathrm{m}^{-2} \mathrm{~h}^{-1}$ ) over the same time interval. The marsh consistently took up dissolved inorganic $\mathrm{N}$ and $\mathrm{P}$ (Fig. 7b) and DOC (Fig. 7c) during the July-August 1991 sampling. The magnitude of temporal variability in inorganic nitrogen flux $(2.6 \pm 0.12$ to $4.5 \pm 0.44 \mathrm{mg}$ $\mathrm{NH}_{4}{ }^{+}-\mathrm{N} \mathrm{m}^{-2} \mathrm{~h}^{-1}$ and $1.2 \pm 0.12$ to $2.4 \pm 0.46 \mathrm{mg} \mathrm{NN}-\mathrm{N}$ $\mathrm{m}^{-2} \mathrm{~h}^{-1}$ ) was not as great as the site-to-site (spatial) variability during the same time period $(-1.4 \pm 1.2$ to $3.1 \pm 0.12 \mathrm{mg} \mathrm{NH}{ }_{4}{ }^{+}-\mathrm{N} \mathrm{m}^{-2} \mathrm{~h}^{-1}$ and $0.03 \pm 0.004$ to $1.8 \pm$ $0.46 \mathrm{mg} \mathrm{NN}-\mathrm{N} \mathrm{m}^{-2} \mathrm{~h}^{-1}$ ). The temporal variability in observed DOC fluxes $\left(280 \pm 16\right.$ to $900 \pm 420 \mathrm{mg} \mathrm{C} \mathrm{m}^{-2}$ 
$\left.\mathrm{h}^{-1}\right)$ was also less than spatial variability $(-440 \pm 220$ to $920 \pm 60 \mathrm{mg} \mathrm{C} \mathrm{m}^{-2} \mathrm{~h}^{-1}$ ) over the same $6 \mathrm{~d}$ time period. Soluble reactive $\mathrm{P}$ fluxes, however, showed greater temporal variability than spatial variability $10.13 \pm 0.2$ to $0.84 \pm 0.02 \mathrm{mg} \mathrm{m}^{-2} \mathrm{~h}^{-1}$ and $0.03 \pm 0.2$ to $0.5 \pm 0.2 \mathrm{mg}$ $\mathrm{m}^{-2} \mathrm{~h}^{-1}$ respectively).

\section{DISCUSSION}

\section{Geomorphological setting}

In a rising sea level scenario, as that of the current Holocene epoch, barrier island-marsh transgression rates are generally determined by local slope and rates of sea level rise. In these dynamic systems, the terrestrial-estuarine ecotone is the site of state change (Hayden et al. 1991, Dame et al. 1992). The result is back-barrier estuarine systems made up of marshes that are actually a mosaic of differing geologic ages, with the youngest marsh nearest the land margin (Gardner \& Bohn 1980, Dame \& Gardner 1993). Theoretically, this spatial gradient of geomorphic age also corresponds to a temporal gradient of ecological development (Dame et al. 1992). The back-barrier marshes of Cumberland Island are built from the rich source of Pleistocene sediments that characterize the Georgia Sea Islands (DePratter \& Howard 1977, Howard \& Frey 1985). Historical movement of the transgressive Cumberland Island system was both inland and southerly, though contemporary migration has probably been stopped by jetty construction at the southern inlet in the 1890s and dredging and sediment removal that began in the early 1950s (Oertel 1977. Griffin \& Henry 1983). In this spatiotemporally dynamic system. Site 1 is geologically youngest (and ecologically immature) while Site 3 is oldest (and ecologically mature). The marsh topographic profiles substantiate this, as Site 3 has a classic creekside levee and is relatively high while Site 1 has a (developmental) ramp-like profile and is lower (Fig. 3). The steplike morphology at Site 2 appears to be intermediate between the two: The 'lower step' marsh is probably a recent depositional feature and developmentally similar to the Site 1 marsh while the 'upper step' marsh is probably more similar to the Site 3 marsh. The Vitousek \& Reiners (1975) and Dame et al. (1992) theories of ecosystem development both suggest that immature systems should sequester nutrients and, in an estuarine setting, sediments. Childers (1993) further suggested that, although most marshes experiencing the 2 to $3 \mathrm{~m}$ tidal range that characterizes Cumberland Island should take up nutrients and release sediments, these flux rates should be greater (at any given tidal range) in geologically younger marshes. The testing of these theories using our Cumberland Island marsh-water column exchange data, however, was compounded by the variable degrees of exposure at our 3 sites - while Site 1 is geologically the youngest and (probably) ecologically the most immature marsh, it is also the most exposed site

\section{Spatial variability in marsh-water column nutrient exchanges}

Only a few studies have used a marsh flume technique to directly measure marsh-water column exchanges, and none sampled more than 1 site per estuary. As previously indicated, the most intensive of these were in Virginia (Wolaver et al. 1980, 1983, Wolaver \& Zieman 1984) and South Carolina (Wolaver \& Spurrier 1988a, b, Wolaver et al. 1988, Whiting et al. 1989), where fluxes were measured approximately every $2 \mathrm{wk}$ for 13 mo. Flume studies have also been conducted at Sapelo Island, Georgia (Chalmers et al. 1985) and in 2 Louisiana estuaries (Childers \& Day 1990 a, b). Childers (1993) placed these past research efforts into the geomorphological framework described above. The South Carolina flume was constructed near the headwaters of Bly Creek, South Carolina (Dame et al. 1991, Dame et al. 1992, Dame \& Gardner 1993) in a geologically young marsh basin that was similar to Site 1 except that the Bly Creek marsh was not exposed to open water influences. The Sapelo Island flume was constructed on the Duplin River in a marsh similar to Site 3 and, we assume, of similar geologic age and origin (notably, Sapelo Island is only about $60 \mathrm{~km}$ north of Cumberland Island). The Louisiana study was conducted in 2 systems at different stages of the deltaic cycle - one estuary is deteriorating while the other is stable. Although marsh-estuarine systems of the Mississippi delta are not readily comparable to transgressive back-barrier systems of the Atlantic coast, degrading marshes are geologically older than developing and stable marshes (Coleman \& Gagliano 1964, Gagliano et al. 1981).

Dissolved inorganic $N$ fluxes were mostly imports at all 3 Cumberland Island sites (Fig. 5a, b), as predicted for marshes in a mesotidal setting (Childers 1993) Ammonium and NN uptake tended to be greater in the summer, following a seasonal pattern similar to the $\mathrm{NH}_{4}{ }^{+}$and NN fluxes at both Carter's Creek, Virginia (Wolaver et al. 1980, 1983) and Bly Creek (Whiting et al. 1989). Spatially, we also observed greater $\mathrm{NH}_{4}{ }^{+}$flux rates at the geologically young Site 1 compared to the older marshes at Sites 2 and 3 (Fig. 5a, b), apparently fitting the Vitousek \& Reiners (1975) model which predicts that successionally younger, ecologically immature ecosystems should sequester nutrients. The geo- 
logically young Bly Creek marsh also consistently imported $\mathrm{NH}_{4}{ }^{+}$and $\mathrm{NN}$ (Whiting et al. 1989). Marshes of the older, deteriorating Louisiana estuary consistently released $\mathrm{NH}_{4}{ }^{+}$and $\mathrm{NN}$ while the young, aggradational marsh imported DIN in the spring and subsequently exported DIN in the late summer and fall in a seasonal pattern somewhat out of phase with our Cumberland Island data (Childers \& Day 1990b).

Phosphorus dynamics are often closely associated with suspended sediments because of the geochemical nature of phosphorus. Although this association is strongest between fine-grained sediments and particulate $\mathrm{P}$, we found relationships between SRP and TSS fluxes at Site $1\left(r^{2}=0.32, p=0.09\right)$ and at Site $2\left(r^{2}=\right.$ $0.56, p=0.05)$ - we found no SRP-TSS flux relationship at Site 3. This potential SRP-TSS association may partially explain why the most evident spatial pattern we observed in SRP fluxes was not in the magnitude of exchange, as with DIN, but in the direction of exchange. In fact, one-third of the 21 SRP fluxes shown in Fig. $5 \mathrm{c}$ were not significantly different from zero. In many samplings, Site 1 SRP flux was in the opposite direction from either Site 2 or Site 3. Site 3 showed the greatest number of SRP fluxes not significantly different from zero, suggesting that this higher, more mature marsh may be closer to an equilibrium with respect to SRP (Fig. 5c). Wolaver \& Spurrier (1988b) reported consistent SRP import by the geologically young Bly Creek marsh, especially during warmer months. Most of that SRP removal occurred in the tall Spartina alterniflora low marsh region, as did most of the $\mathrm{NH}_{4}{ }^{+}$ uptake described above. Wolaver et al. (1985) defined this segment of the marsh as the first $22 \mathrm{~m}$ of their flume, roughly equivalent to the $30 \mathrm{~m}$ enclosed in our flumes. Although the SRP flux data from Site 1 do not reflect this consistent uptake through the year, Sites 2 and 3 did tend to behave similarly and exchange less SRP than the geologically younger Site 1 marsh. As with the DIN data, our SRP fluxes also fit the nutrient uptake scenarios of Vitousek \& Reiners (1975) and Childers (1993).

In the 1970s, it was suggested that salt marshes may supply DOC to the estuary by virtue of the observation that Spartina alterniflora leaches dissolved organics (Wetzel \& Manny 1972, Gallagher et al. 1976, Pomeroy et al. 1977). We measured significant DOC export by Cumberland Island salt marshes in only one-third of samplings, and these releases mostly occurred at Sites 2 and 3 . The geologically younger Site 1 generally imported DOC, and flux rates were often greater than those measured at Sites 2 and 3 (Fig. 5d). This pattern was similar to the Louisiana flume data, where Childers \& Day (1990b) reported DOC uptake by the younger deltaic marsh and DOC release by the older marshes. This pattern also appeared to contradict the prediction that mesotidal marshes tend to import DOC, with greater flux rates in geologically young marshes (Childers 1993). The geologically young Bly Creek salt marsh imported DOC, though the net annual flux was not statistically significant (Wolaver \& Spurrier 1988a), and Chalmers et al. (1985) also found no consistent evidence for DOC release by the Sapelo Island salt marsh. Our data (particularly from Sites 2 and 3), showing DOC fluxes that were variable in both magnitude and direction, were consistent with their findings (Fig. 5d). Marshes do appear to be significant sources of DOC to the estuary during low tide drainage (Wolaver \& Spurrier 1988a), during rainstorms while exposed (Chalmers et al. 1985, Wolaver \& Spurrier 1988a), and when DOC fluxes measured both during tidal inundation and following tidal recession (low tide drainage) were combined (Childers et al. 1993). At Cumberland Island, however, we measured a large and significant DOC uptake at Site 2 during a July 1991 rain event $\left(0.92 \mathrm{~g} \mathrm{~m}^{-2} \mathrm{~h}^{-1}\right)$ during low tide drainage of the 'upper step' feature of this marsh, after tidal recession (Table 1, Fig. 5d).

Earlier, we hypothesized that dissolved nutrient fluxes should be largely controlled by inundation rates (hence site-to-site topographic variability) and seasonality, rather than by climatologic factors and exposure. The topographic 'step' feature at Site 2 and the high berm at Site 3 prevented complete inundation of these marshes on many tides (Table 1, Fig. 3). This reduced both the area of marsh exposed to flooding waters and the duration of marsh exposure which, in turn, may affect both active and diffusive exchanges of dissolved constituents. Not unexpectedly, our 'degree of neapspring influence' (see Table 2 legend for definition) was a significant predictor of both slack high tidal elevation (HTWL in Table 1) and integrated area inundated $\left(r^{2}=0.54, p<0.001\right.$ and $r^{2}=0.19, p=0.03$ respectively). The 'degree of neap-spring influence' explained $89 \%$ of the variability in HTWL at Site $3(\mathrm{p}=$ $0.001)$ compared to only $38 \%$ at Site $1(p=0.059)$, suggesting that non-astronomical factors - namely wind forcing - may have a much greater influence on actual water levels at the most exposed flume site (Site 1) compared to the most protected site (Site 3). In the neap-spring influence versus area regression, the differing marsh topographies also generated distinct hypsometric relationships. Only the ramp-like profile at Site 1 showed relatively linear hypsometry.

We observed a relatively coherent seasonal pattern in the DIN fluxes and, to some extent, in the SRP fluxes. We also found a number of interesting relationships between the tidal hydrologic variables discussed above and DIN, SRP, and DOC fluxes (Table 2). In all cases shown, a large percentage of the variability in flux $(58$ to $78 \%)$ was explained by variation in area 
Table 2. Regressions of various fluxes (dependent variable) and tidal hydrologic variables that were significant at $p \leq 0.05$. Tidal hydrologic (independent) variables included integrated area inundated by each tide $\left(\mathrm{m}^{2}\right)$, tide height at slack high water (cm above NGVD) and a neap $\rightarrow$ spring variable with neap tidal ranges $=0$ and spring tidal ranges $=50$ (calculated as the absolute value of Tide -50 ; Tide from Table 1). Fluxes of inorganic nutrients, TSS, and OSS are in $\mathrm{mg} \mathrm{m}^{-2} \mathrm{~h}^{-1}$; DOC fluxes are in $\mathrm{g} \mathrm{m}^{-2}$ $\mathrm{h}^{-1}$ Positive flux represents uptake by the marsh, negative flux is export from the marsh. I-E switch, where the flux pattern switches from export to import (positive slope) or from import to export (negative slope): value of the independent variable where estimated flux $=0$

\begin{tabular}{|c|c|c|c|c|c|}
\hline Independent variable & Dependent variable & $r^{2}$ & $\mathrm{p}$ & Slope & I-E switch \\
\hline \multicolumn{6}{|l|}{ Site 1 data } \\
\hline Area inundated & Ammonium flux & 0.75 & $<0.001$ & -1.36 & 26.4 \\
\hline Area inundated & Nitrate+nitrite flux & 0.78 & $<0.001$ & -0.72 & 25.8 \\
\hline Area inundated & Soluble reactive P flux & 0.63 & 0.006 & -0.59 & 25.5 \\
\hline Area inundated & DOC flux & 0.59 & 0.015 & -0.10 & 28.5 \\
\hline \multicolumn{6}{|l|}{ Site 2 data } \\
\hline Area inundated & TSS flux & 0.76 & 0.01 & 1370 & 19.9 \\
\hline Area inundated & OSS flux & 0.76 & 0.011 & 255 & 20.2 \\
\hline Maximum tide height & TSS flux & 0.86 & 0.003 & 206 & 211 \\
\hline Maximum tide height & OSS flux & 0.87 & 0.002 & 38.5 & 213 \\
\hline \multicolumn{6}{|l|}{ Site 3 data } \\
\hline Maximum tide height & Nitrate+nitrite flux & 0.76 & 0.011 & 0.02 & 197 \\
\hline Maximum tide height & TSS flux & 0.81 & 0.006 & 145 & 204 \\
\hline Maximum tide height & OSS flux & 0.82 & 0.005 & 31.6 & 204 \\
\hline Neap $\rightarrow$ spring $(0 \rightarrow 50)$ & Nitrate+nitrite flux & 0.58 & 0.048 & 0.04 & 14.7 \\
\hline Neap $\rightarrow$ spring $(0 \rightarrow 50)$ & TSS flux & 0.84 & 0.004 & 400 & 18.9 \\
\hline Neap $\rightarrow$ spring $(0 \rightarrow 50)$ & OSS flux & 0.78 & 0.008 & 83.5 & 19.0 \\
\hline \multicolumn{6}{|l|}{ All sites pooled } \\
\hline Maximum tide height & TSS flux & 0.24 & 0.014 & 144 & 228 \\
\hline Maximum tide height & OSS flux & 0.21 & 0.026 & 27.5 & 235 \\
\hline Neap $\rightarrow$ spring $(0 \rightarrow 50)$ & TSS flux & 0.20 & 0.028 & 327 & 28.4 \\
\hline Neap $\rightarrow$ spring $(0 \rightarrow 50)$ & OSS flux & 0.15 & 0.06 & 58.9 & 32.0 \\
\hline
\end{tabular}

inundated, maximum tidal height, and neap-spring influence. Most notably was the dramatically different flux behavior at Site 1 compared to Sites 2 and 3. Regressions of area inundated against Site 1 dissolved constituent fluxes all generated negative slopes, implying reduced rates of uptake as tidal range increased to a point where flux actually switched to export at long inundations (Table 2). This compared to positive relationships between NN flux and slack high tidal height, and between NN flux and spring-neap influence, at Site 3 and no dissolved constituent relationships at Site 2. Again, the data suggested differences in the way the geologically young Site 1 marsh interacts with the estuary compared to geologically older Sites 2 and 3.

\section{Spatial variability in marsh-water column sediment exchanges}

The marsh development paradigm holds that coastal marsh sedimentation must (at least) equal apparent sea level rise for the marsh to remain subaerial (Redfield 1972). Generalizations about particulates fluxes related to the geologic age of marshes are difficult. except in deltaic estuaries, and exposure is a critical confounding variable. The geologically young Bly Creek marsh imported TSS, OSS (Wolaver et al. 1988) and POC (Wolaver \& Spurrier 1988a), and the older Sapelo Island marsh took up POC (Chalmers et al. 1985). Particulates uptake by the Sapelo Island marsh was markedly greater than at Bly Creek. At Site 1, we measured onshore winds and steep, erosive waves within the flume 5 of 7 times, compared to only once at Site 2 and never at Site 3 (Table 1). Total suspended sediments and OSS were exported from the exposed Site 1 marsh during all but 1 sampling, including the 2 events without wave activity (Fig. 6). In fact, the differences in topographic profiles may be a key to observed patterns in particulates fluxes. Flux-tidal hydrology regressions suggested that, at Site 2 , the area inundated explained $76 \%$ of the variability in TSS and OSS fluxes and slack high tidal elevation explained 86 and $87 \%$, respectively (Table 2 ). We found similar relationships with Site 3 fluxes and both slack high tidal elevation and neap-spring influence, but not with the Site 1 flux data. In all cases, these highly significant relationships generated positive slopes (Table 2). At Site 2, 
particulates fluxes switched from release to uptake only when maximum tidal heights exceeded about $2 \mathrm{~m}$ above NGVD (National Geodetic Vertical Datum) high enough to flood the 'upper step' feature (see Fig. 3b). The Site 2 marsh exported sediments when only the 'lower step' feature was inundated, a flux pattern more characteristic of Site 1. This further substantiated our conceptualization of Site 2 as developmentally intermediate between Sites 1 and 3 . The export to import inflection in the Site 3 regressions was also at the point where the tide was great enough to inundate the entire marsh (about $2.3 \mathrm{~m}$ above NGVD; Table 2 and Fig. 3c). When particulates fluxes from all 3 sites were pooled, we found significant relationships with both maximum tide height and neap-spring influence. Although explaining only 15 to $24 \%$ of the variability in TSS and OSS flux, the implication is that most Cumberland Island marshes take up sediments only when tidal heights exceed about $2.3 \mathrm{~m}$ above NGVD (Table 2 ). This corresponds to tides where the moon is within $20 \%$ of new or full phase (= 'degree of neap-spring influence' of 30 to 50 ), or approximately $40 \%$ of the time.

\section{Temporal variability in marsh-water column exchanges}

Sampling with marsh flumes is a time- and sampleintensive effort, and for this reason few investigators have been able to dedicate the resources necessary to sample multiple consecutive tidal cycles. Wolaver et al. (1985) sampled the Bly Creek flume over 2 consecutive tidal cycles during their calibration study. The first inundated little of the marsh while the second inundated most of the flume, and flux data for NN and POC reflected this difference. The marsh released $27.4 \mathrm{mg}$ $\mathrm{NN}-\mathrm{N}$ tidal cycle $^{-1}$ in the second tidal cycle compared to $5.4 \mathrm{mg} \mathrm{NN}-\mathrm{N}$ tidal cycle ${ }^{-1}$ in the first, and actually imported POC during the low-range tide while exporting POC during the high-range tide. It was not logistically possible to sample all 3 Cumberland Island flumes on the same day. We were able to investigate the short-term temporal variability inherently nested in our spatial data sets, though, by sampling marshwater column fluxes at 1 site on 3 consecutive days immediately after sampling all 3 sites.

Site 1 was chosen to quantify temporal variability in marsh-water column exchanges because, being the most exposed site, it was most succeptible to daily variations in weather (see wind vane diagrams, Fig. 7) Over the $6 \mathrm{~d}$, 11-tidal cycle time interval sampled in July-August 1991, the marsh consistently exported particulates while importing all dissolved constituents (Fig . 7). The temporal variability in TSS and OSS fluxes was considerably greater than the spatial variability over the same time, although that inequity was largely related to the major export on 2 August (Figs. 6a \& 7a). On this day, strong SW winds blowing directly into the flume generated waves in excess of $30 \mathrm{~cm}$, eroding and washing out nearly $28 \mathrm{~g} \mathrm{TSS} \mathrm{m}^{-2} \mathrm{~h}^{-1}$. Without that event, the mean export (of 30 July to 4 August fluxes) was $6.9 \mathrm{~g} \mathrm{TSS}^{-2} \mathrm{~h}^{-1}( \pm 5.0)$ and $1.7 \mathrm{~g} \mathrm{OSS} \mathrm{m}^{-2} \mathrm{~h}^{-1}$ $( \pm 1.3)$, neither of which was significantly different from the fluxes measured during our spatial sampling on 30 July $\left(-3.63 \pm 1.35 \mathrm{~g} \mathrm{TSS} \mathrm{m}^{-2} \mathrm{~h}^{-1}\right.$ and $0.8 \pm 0.3 \mathrm{~g}$ OSS $\left.\mathrm{m}^{-2} \mathrm{~h}^{-1}\right)$. Apparently, the short-term temporal variability observed in particulates fluxes does not play a major role in spatial variability except during extreme wind events. In fact, it may be more important for a marsh flume sampling regime to represent the full spectrum tidal regimes than to intensively sample consecutive tidal cycles in an effort to capture temporal variability.

The day-to-day variability in dissolved constituents fluxes measured at Site 1 (Fig. 7b, c) was considerably less than the NN flux data reported by Wolaver et al. (1985). In fact, although the 30 July to 4 August dissolved constituents fluxes were different from each other, the 30 July flux data that represented Site 1 in the spatial analysis $\left(3.1 \pm 0.1 \mathrm{mg} \mathrm{NH}_{4}{ }^{+}-\mathrm{N} \mathrm{m}^{-2} \mathrm{~h}^{-1}, 1.2 \pm\right.$

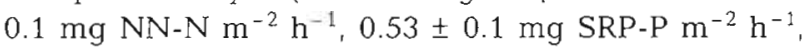
and $280 \pm 10 \mathrm{mg}$ DOC-C m${ }^{-2} \mathrm{~h}^{-1}$ ) generally fell within the range of the temporal variability over that $6 \mathrm{~d}, 11$ tidal cycle interval (as means: $3.5 \pm 0.83 \mathrm{mg} \mathrm{NH}_{4}{ }^{+}-\mathrm{N}$ $\mathrm{m}^{-2} \mathrm{~h}^{-1}, 2.0 \pm 0.57 \mathrm{mg} \mathrm{NN}-\mathrm{N} \mathrm{m}^{-2} \mathrm{~h}^{-1}, 0.55 \pm 0.31 \mathrm{mg}$ SRP-P m ${ }^{-2} \mathrm{~h}^{-1}$ and $640 \pm 320 \mathrm{mg}$ DOC-C $\mathrm{m}^{-2} \mathrm{~h}^{-1}$ ). Furthermore, in summer 1991 we observed more variability in DIN and DOC fluxes across space (Sites $1 \rightarrow 3$; Fig. 5) than we observed across time (30 July $\rightarrow 4$ August; Figs. $7 \mathrm{~b}, \mathrm{c}$ ), suggesting that short-term variability in dissolved constituents fluxes was not a major contribution to spatial variability independent of extreme wind events. Interestingly, since temporal variability in SRP fluxes was greater than spatial variability, this conclusion may not apply to marsh-water column exchanges of SRP.

Acknowledgements. The authors thank the Cumberland Island research staff of the National Park Service for permission to use the National Park for research and for logistical assistance with field work. In particular, we are very grateful to G. Forrester and B. Zoodsma for their invaluable help with boat operations and on-site logistics, to P. Webster and $W$. Johnson for preparing nutrient samples and running all nutrient analyses, to $\mathrm{S}$. Hutchinson for help with initial fractal models of marsh topography, and to E. Melaro and a host of assistants from Woodward-Clyde Consultants for their help with flume construction and sampling. N. Dankers, J. Fourqurean, S. Hutchinson, and an annonymous reviewer provided helpful comments on early manuscript drafts. Funding 
for this research was received from the Department of the Navy through an Interagency Agreement (IA 5000-8-8002) with the Department of the Interior, National Park Service. Contemporary support was also provided to D.L.C. by National Science Foundation Grant No. BSR-8906269. This publication is Contribution No. 968 of the Belle W. Baruch Institute for Marine Biology and Coastal Research. This paper is dedicated to the memory of William E. Odum, whose energy, enthusiasm, and integrity we will never forget.

\section{LITERATURE CITED}

Bowden, W. B. (1986). Nitrification, nitrate reduction, and nitrogen immobilization in a tidal fresh-to-brackish marsh sediment. Ecology 67(1): 88-99

Chalmers, A. G., Wiegert, R. G., Wolf, P. L. (1985). Carbon balance in a salt marsh: interactions of diffusive export, tidal deposition, and rainfall-caused erosion. Estuar. coast. Shelf Sci. 21: $757-771$

Childers, D. L., Day, J. W. Jr (1988). Direct quantification of nutrient and material fluxes between microtidal Gult Coast wetlands and the estuarine water column. Estuar. coast. Shelf Sci. 27: 483-494

Childers, D. L., Day, J. W. Jr (1990a). Marsh-water column interactions in two Louisiana estuaries. I. Sediment dynamics. Estuaries 13(4): 393-403

Childers, D. L., Day, J. W. Jr (1990b). Marsh-water column interactions in two Louisiana estuaries. II. Nutrient dynamics. Estuaries 13(4): 404-417

Childers, D. L., McKellar, H. N. Jr, Dame, R., Sklar, F., Blood, E. (1993). A dynamic nutrient budget of subsystem interactions in a salt marsh estuary. Estuar. coast. Shelf Sci. 36: $105-131$

Childers, D. L. (1993). Fifteen years of marsh flumes - a review of marsh-water column interactions in Southeastern USA estuaries. Proc. INTECOL Fourth International Wetlands Conf. Elsevier Press, Amsterdam (in press)

Coleman, J. M., Gagliano, S. M. (1964). Cyclic sedimentation in the Mississippi River deltaic plain. Trans. Gulf Coast Ass. geol. Soc. 14:67-80

Dame, R. F. (1993). The net flux of materials between marshestuarine systems and the sea: the Atlantic coast of the U.S. Proc. INTECOL Fourth International Wetlands Conf. Elsevier Press, Amsterdam (in press)

Dame, R. F., Childers, D. L., Koepfler, E. T (1992). A geohydrologic continuum theory for the spatial and temporal evolution of marsh-estuarine ecosystems. Neth. J. Sea Res. 30: $1-8$

Dame, R. F., Gardner, L. R. (1993). The influence of sea level rise and tidal creek development on nutrient cycling in a southeastern marsh-estuarine ecosystem. Mar. Chem. (in press)

Dame, R. F., Spurrier, J. D., Williams, T. M., Kjerfve, B., Zingmark, R. G., Wolaver, T. G., Chrzanowski, T. H., McKellar, H. N., Vernberg, H. N. (1991). Annual material processing by a salt marsh estuarine basin in South Carolina. Mar. Ecol. Prog. Ser. 72: 153-166

DePratter, C. B., Howard, J. D. (1977). History of shoreline changes determined by archaeological dating: Georgia coast, USA. Trans. Gulf Coast Ass. geol. Soc, 27 : $252-258$

Gagliano, S. M., Meyer-Arendt, K. J., Wicker, K. M. (1981). Land loss in the Mississippi River deltaic plain. Trans. Gulf Coast Ass. geol. Soc. 31: 295-300

Gallagher, J. L., Pfeiffer, W. J., Pomeroy, L. R. (1976). Leaching and microbial utilization of DOC from leaves of Spar- tina alterniflora. Estuar. coast. mar. Sci. 4: 467-478

Gardner, L. R., Bohn, M. (1980). Geomorphic and hydraulic evolution of tidal creeks on a subsiding beach ridge plain, North Inlet, SC. Mar. Geol. 34: M91-M97

Griffin, M. M., Henry, V. J. (1983). Historical changes in the mean high water shoreline of Georgia, 1857-1982. Tech. Rept. Ga geol. Survey, Atlanta

Hayden, B. P., Dueser, R. D., Callahan, J. T., Shugart, H. H. (1991). Long-term research at the Virginia Coastal Reserve. BioSci. 41(5): 310-318

Howard, J. D., Frey, R. W. (1985). Physical and biogenic aspects of backbarrier sedimentary sequences, Georgia Coast, USA. Mar. Geol. 63: 77-127

Lee, V. (1979). Net nitrogen flux between the emergent marsh and tidal waters. M.Sc. thesis, Univ. Rhode Island, Kingston

Nixon, S. W. (1980). Between coastal marshes and coastal waters: a review of 20 years of speculation and research on the role of saltmarshes in estuarine productivity and water chemistry. In: Hamilton P., MacDonald, K. B. (eds.) Estuarine and wetland processes. Plenum Press, New York, p. 437-525

Odum, W. E., Fisher, J. S., Pickral, J. C. (1979). Factors controlling the flux of POC from estuarine wetlands. In: Livingston, R. J. (ed.) Ecological processes in coastal and marine systems. Plenum Press, New York, p. $69-80$

Oertel, G. F. (1977). Geomorphic cycles in ebb deltas and related patterns of shore erosion and accretion. J. sedim. Petrol. 47: 1121-1131

Pomeroy, R. L., Bankroft, K., Breed, J., Christian, R. R., Frankenberg, D., Hall, J. R., Maurer, G. G., Wiebe, W. J., Wiegert, R. G., Wetzel, R. L. (1977). Flux of organic matter through a saltmarsh. In: Wiley, M. (ed.) Estuarine processes. Academic Press, New York, p. 270-281

Redfield, A. C. (1972). The development of a New England saltmarsh. Ecol. Monogr. 42: 201-237

Sokal, R. R., Rohlf, F. J. (1981). Biometry. W. H. Freeman and Co., San Francisco

Stevenson, J. C., Ward, L. G., Kearney, M. S. (1988). Sediment transport and trapping in marsh systems: implications of tidal flux studies. Mar. Geol. 80: 37-59

Spurrier, J D., Kjerfve, B. (1988). Estimating the net flux of nutrients between a salt marsh and a tidal creek. Estuaries 11(1): $10-14$

U.S. E.P.A. (United States Environmental Protection Agency) (1979). Standard methods for chemical analysis of water and wastewater. NERC EPA-62516-741003. Methods Development Quality Assurance Research Laboratory, Washington, DC

Vitousek, P. M., Reiners, W. A. (1975). Ecosystem succession and nutrient retention: a hypothesis. BioSci. 25: $376-381$

Wetzel, R. G., Manny, B. A. (1972). Secretion of DOC and nitrogen by aquatic macrophytes. Verh. int. Verein. Limnol. 18: 162-174

Whiting, G. J., McKellar, H. N., Wolaver, T G. (1989). Nutrient exchange between a portion of vegetated saltmarsh and the adjoining creek. Limnol. Oceanogr. 34(2): $463-473$

Wolaver, T., Dame, R., Spurrier, J. D., Miller, A. B. (1988). Sediment exchange between a euhaline saltmarsh in South Carolina and the adjacent tidal creek. J. coast. Res. 4(1): $17-26$

Wolaver, T G., Spurrier, J D. (1988a). Carbon transport between a euhaline vegetated marsh in South Carolina and the adjacent tidal creek: contributions via tidal inun- 
dation, runoff, and seepage. Mar. Ecol. Prog. Ser. 42: $53-62$

Wolaver, T. G., Spurrier, J. D. (1988b). The exchange of phosphorus between a euhaline vegetated marsh and the adjacent tidal creek. Estuar. coast. Shelf Sci. 26: 203-214

Wolaver, T G., Wetzel, R. L., Zieman, J. C., Webb, K. L. (1980). Nutrient interactions between salt marsh, mudflats, and estuarine water. In: Kennedy V. S. (ed.) Estuarine perspectives. Academic Press, New York, p. 123-133

Wolaver, T. G., Wetzel, R. L., Zieman, J. C., Webb, K. L. (1983). Tidal exchange of nitrogen and phosphorus

This article was submitted to the editor between a mesohaline vegetated marsh and the surrounding estuary in the Lower Chesapeake Bay. Estuar. coast. Shelf Sci. 16: 321-332

Wolaver, T., Whiting, G., Kjerfve, B., Spurrier, J., McKellar, H., Dame, R., Chrzanowski, T., Zingmark, R., Williams, T. (1985). The flume design - a methodology for evaluating material fluxes between a vegetated salt marsh and the adjacent tidal creek. J. exp. mar. Biol. Ecol. 91: 281-291

Wolaver, T G., Zieman, J. C. (1984). Effect of water column, sediment, and time over the tidal cycle on the chemical composition of tidal water in a mesohaline marsh. Mar. Ecol. Prog. Ser. 12: 123-130

Manuscript first received: August 13, 1992

Revised version accepted: March 4, 1993 